\title{
FROM EGYPT, WITH LOVE: LEPSIUS AND THE TRADITION OF WRITING MODERN NAMES IN EGYPTIAN HIEROGLYPHS
}

\author{
Pavel Onderka - Christian E. Loeben ${ }^{1}$
}

\begin{abstract}
The present article surveys Karl Richard Lepsius' (1810-1884) love for producing modern compositions of Egyptian hieroglyphic texts, and in particular, for writing modern names in Egyptian hieroglyphs. The survey is carried out in the context of new discoveries of such texts on objects kept in the collections of Museum August Kestner in Hanover and the National Museum - Náprstek Museum of Asian, African and American Cultures in Prague. Two newly identified and interpreted texts come from the bases of modern imitations of ancient Egyptian scarabs, which were produced - no doubt under the supervision of Lepsius himself - in a local workshop at Luxor, Upper Egypt, in 1845. As a matter of fact, Lepsius stood at the origins of a still ongoing and extremely popular souvenir production, which employs transcriptions of modern names into hieroglyphs.
\end{abstract}

KEYWORDS: Karl Richard Lepsius - scarabs - forgeries - Egyptian hieroglyphs

\section{Introduction}

History of reproducing, imitating, and forging ancient Egyptian antiquities is almost as old as the interests in the history of the land on the Nile itself. Each and every Egyptian collection across the globe contains a certain number of forgeries and imitations. It was only with the decipherment of Egyptian hieroglyphs by Jean-François Champollion in 1822 and the subsequent precision of their understanding by - above all - Karl Richard Lepsius (1810-1884) that enabled hieroglyphic texts to be reproduced, or even forged, in a corresponding quality (with the help of professional Egyptologists). The very first author of modern hieroglyphic composition was no one else but Lepsius, whose fondness in this kind of enterprise has been well-known. In the past decade, two Lepsius's compositions were identified on objects kept in the collections of the National Museum - Náprstek Museum of Asian, African and American Cultures in Prague and Museum August Kestner in Hanover.

1 Contacts: Pavel Onderka, National Museum - Náprstek Museum of Asian, African and American Cultures, Ancient Near East and Africa Collection, Prague, Czech Republic; e-mail: pavel.onderka@nm.cz; Christian E. Loeben, Museum August Kestner, Hanover, Germany/ Lecturer in Egyptology and Ancient Cultures, University of Göttingen, Germany; e-mail: Christian.Loeben@hannover-stadt.de. This work was financially supported by Ministry of Culture of the Czech Republic (DKRVO 2019-2023/18.III.b, National Museum, 00023272). The authors are indebted to Franziska Naether, Friederike Seyfried, Robert Kuhn, and Adam Grubner for their suggestions and comments. The authors wish to dedicate the present article to Emily Teeter (Chicago) for her friendship, kindness, endless support, and devotion to Egyptology and Egyptian collections in particular.

This work is licensed under the Creative Commons Attribution-Noncommercial-No Devivs 3.0 License 
Karl Richard Lepsius was a German - or more precisely Prussian - Egyptologist, linguist, and archaeologist. The native of Naumburg an der Saale studied Classical Archaeology at the universities in Leipzig, Göttingen, and Berlin. After his dissertation in 1833, he travelled to Paris and continued in the work of Jean-François Champollion on the decipherment of ancient Egyptian language, analysing his Grammaire égyptienne. ${ }^{2}$ Lepsius elaborated on the ancient language in a series of 'letters' addressed to Champollion's colleague, Ippolito Rosellini (1800-1843). In these letters, Lepsius, inter alia, redefined the 'General phonetic alphabet' of ancient Egyptian through equating Coptic letters with ancient Egyptian uniliteral (and several biliteral) signs [Fig. 1].

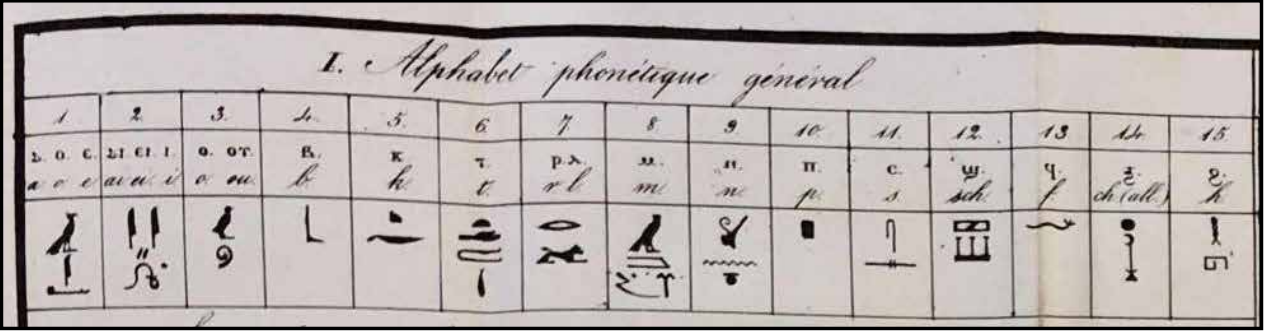

Fig. 1. 'General phonetic alphabet' from Lepsius's Lettre à M. le professeur H. Rosellini [...] sur l'alphabet hiéroglyphique (Lepsius 1837, Pl. A).

In 1842, King Friedrich Wilhelm IV of Prussia (1795-1861; r. 1840-1861) commissioned Lepsius to lead a scientific expedition (modelled upon the Napoleonic pattern and following the example of the Prussian expedition led by Henrich Menu von Minutoli [1772-1846] of 1820-1821 and the joint Franco-Tuscan expedition to Egypt of 18281829 led by Champollion and Rosellini which would explore and record monuments of the ancient civilisations of Egypt and the Sudan.

\section{The Lepsius Graffiti above the entrance to the Great Pyramid at Giza}

After several weeks of preparations in Alexandria, the expedition set sail upstream to Cairo on 1 October 1842. On 15 October 1842, Lepsius and other expedition members celebrated the birthday of King Friedrich Wilhelm in the environs of Cairo. On that occasion they climbed to the top of the Great Pyramid in Giza. The event was captured in the famous aquarelle of the expedition's draughtsman Johann Jakob Frey (1813-1865) [Pl. 1]. During this visit, Lepsius inscribed an Egyptian hieroglyphic graffito above the original entrance to the inner rooms of the Great Pyramid. A similar text was also inscribed around the frame of Frey's aquarelle. The text was also reproduced in Lepsius' letter dated to 17 January 1843 and located in Giza. ${ }^{3}$

The graffito [Fig. 2] was organized into eleven columns representing a sort of congratulatory text to the king of Prussia. The first two and a half columns (Columns 1-3) mention the names of the expedition members who participated on the conquering of the Great Pyramid and who were depicted on Frey's aquarelle: Karl Richard Lepsius, Georg Erbkam (1811-1876), the Weidenbach brothers - Maximilian (1823-1890) and

2 Champollion 1836.

3 Lepsius 1852, p. 30. 


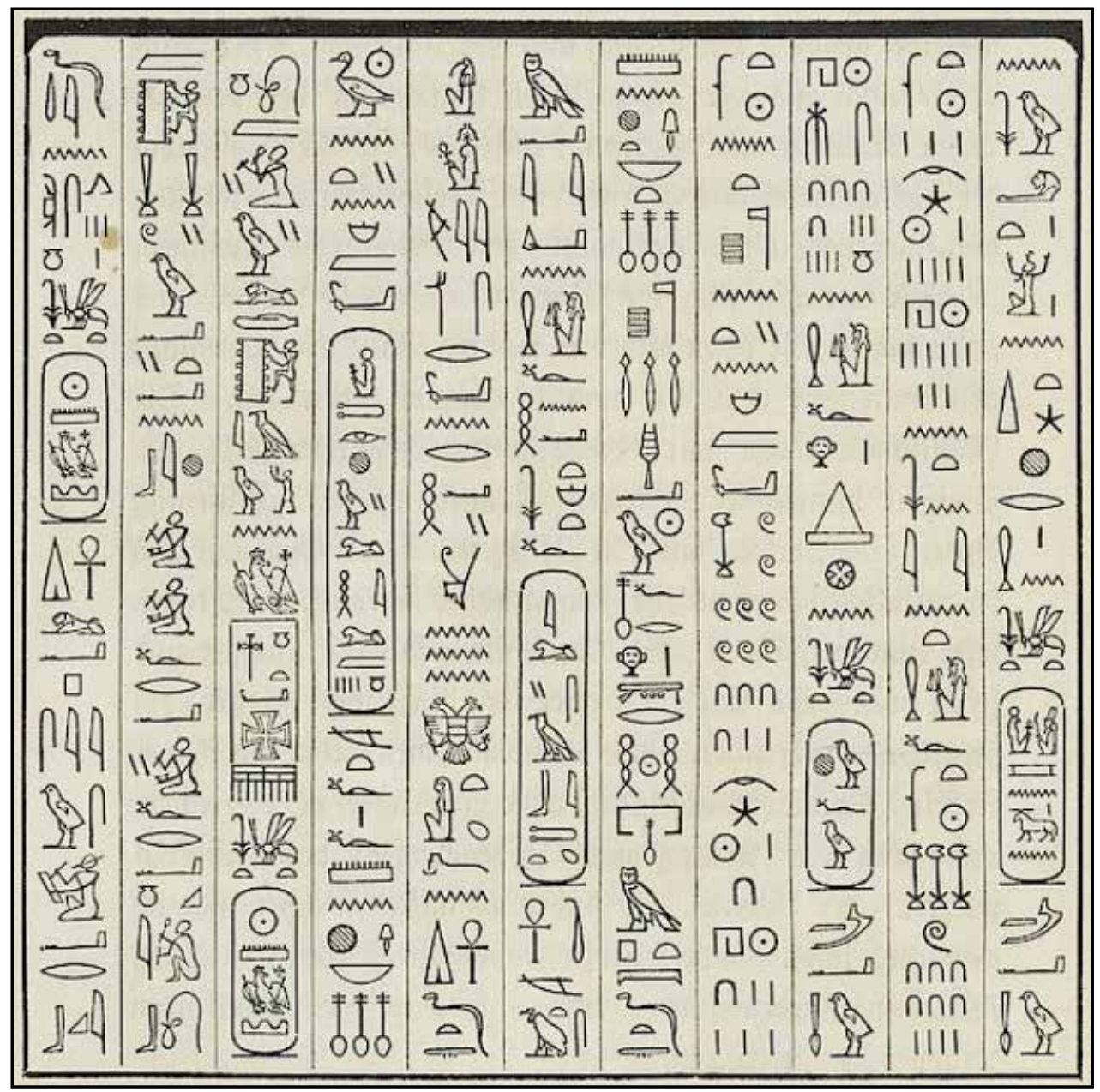

Fig. 2. Transcription of the Giza graffiti in Lepsius's Briefe aus Aegypten, Aethiopien und der Halbinsel des Sinai (Lepsius 1852, p. 30).

Ernst (1818-1882), Johann Jakob Frey, Carl W. Franke (1814-?), and Joseph Bonomi, Jr. (1796-1878). In the text, the expedition members are described as the servants (possibly subjects) of the king. Then follows the pseudo-Egyptian titulary of King Friedrich Wilhelm IV and his wife, Queen Elisabeth (1801-1873) in Columns 3-8. In Columns 8-11 the dating of the event is provided, namely in three different forms: (1) year, month, and day of the Christian/Common Era, (2) reign of King Friedrich Wilhelm IV of Prussia - years, months, and days that had passed since the beginning of his reign, and (3) the number of years which had passed since the beginning of the second dynastic Sothis cycle. In his letter of 17 January 1843, Lepsius translated the inscription in the following words:

(1) So sprechen die Diener des Königs, des Name Sonne und Fels Preußens ist, Lepsius der Schreiber, Erbkam (2) der Architekt, die Brüder Weidenbach die Maler, Frey der Maler, Franke der Former, Bonomi (3) der Bildhauer, Wild der Architekt: Heil dem 
Adler, Schirmer des Kreuzes, dem Könige Sonne und Fels Preußens, (4) dem Sohne der Sonne, die das Vaterland befreite, Friedrich Wilhelm dem Vierten, dem Philopator, dem Landesvater, dem Huldreichen, dem Lieblinge (5) der Weisheit und der Geschichte, dem Hüter des Rheinstroms, den Deutschland erkoren, dem Lebenspender allezeit. (6) Möge gewähren dem Könige und seiner Gemahlin der Königin Elisabeth, der Lebensreichen, der Philometor, der Landesmutter, (7) der Huldreichen, der Höchste Gott ein immer frisches Leben auf Erden für lange und eine selige Wohnung im Himmel für ewig. (8) Im Jahre unseres Heilandes 1842, im zehnten Monat, am fünfzehnten Tage, am siebenundzwanzigsten (9) Geburtstage Seiner Majestät, auf der Pyramide des Königs Cheops; (10) im dritten Jahre, im fünften Monat, am neunten Tage der Regierung Seiner Majestät; im Jahre 3164 (11) vom Anfange des Sothisperiode unter dem Könige Menphthes. ${ }^{4}$

\section{Titulary of Crown Princess Elisabeth}

The graffito was certainly not the first such hieroglyphic composition Karl Richard Lepsius created. For example, in a letter to his father Karl Peter Lepsius (1775-1853) dated 26 February 1840, Lepsius wrote in Egyptian hieroglyphs the name and titles of Crown Princess Elisabeth (wife of the then Crown Prince and future King Friedrich Wilhelm IV). Lepsius titled her - in ancient Egyptian script and language - as Royal ${ }^{5}$ Wife, Royal Daughter, and Royal Sister. Her name is followed by titles and names of her royal husband, father, and brother - Crown Prince Friedrich Wilhelm of Prussia, late King Maximilian I Joseph of Bavaria (1756-1825; r. 1799-1825), and King Ludwig of Bavaria (1786-1868; r. 1825-1848), respectively:

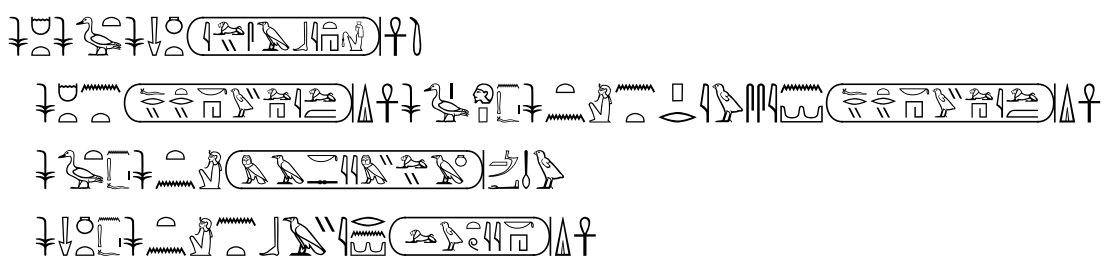

Royal Wife, Royal Daughter, Royal Sister Elisabeth, given life; Royal Wife of Friedrich Wilhelm [IV], given life, the first Royal Son of His Majesty the king of Prussia, Friedrich Wilhelm [III], given life; Royal Daughter of His Majesty, King Maximilian, justified ${ }^{6}$; and Royal Sister of His Majesty King of Bavaria, Ludwig [I], given life.

\section{Scarab Hanover Inv. No. 2151}

From the diary of Georg Erbkam, the member of the Royal Prussian expedition, we learn about another hieroglyphic composition by Lepsius dated to a return phase of the

4 Lepsius 1852, p. 31.

5 The translation 'royal' ('königlich(e)' in German) is given preference to 'King's' with regard to the historical circumstances. Friedrich Wilhelm (IV) of Prussia, husband of Princess Elisabeth Ludovika of Bavaria, ascended the throne only on 4 June 1840, i.e. some three months after the letter had been composed.

6 The epithet 'given life' ( $\left.\underline{d}_{j}{ }^{\top} n h\right)$ was ascribed to living persons or those who were supposed to live forever, while the epithet 'justified' ( $\left.m 3^{\top} h r w\right)$ was given to those that had passed away or were in the future to pass away. 
expedition. On 16 May 1845, while staying in Thebes, in the course of the expedition's return to the north, Erbkam recorded the following note into his diary: 'Gestern schenkte uns Leps[ius] jedem einen Skarabäus mit unsern Namen, gefertigt aus d[em] glasierten Stein: Hammer? eine Art Kalkstein oder Speckstein. ${ }^{7}$ Erbkam omitted to mention that the names were written in Egyptian hieroglyphs, which, to him, might have seemed self-evident.

These scarabs with names were produced not only for the expedition members (as mentioned in Erbkam's diary), but also for Lepsius' friends, donors, and other people of special importance in Europe, including a scarab, bearing the surname of August Kestner (1777-1853), now kept in the collections of Museum August Kestner in Hanover (Inv. No. 2151) [Pl. 2]. Despite being in the museum's collection for over a century and a half, the scarab was only recently reproduced and published in a cursory fashion. ${ }^{8}$

August Kestner (1777-1853) studied law at the University of Göttingen and later became ambassador of the Kingdom of Hanover - and thus also of the United Kingdom - at the Holy See in Rome where he almost continuously lived from 1817 until his death. There, he developed into an enthusiastic collector of antiquities, who spared no effort in acquiring objects from Egypt even in Italy. For this reason, he can be regarded worldwide not only as the first important private collector of Egyptian art, but also as one of the first researchers of Egypt. He was, in fact, personally informed about the progress of deciphering hieroglyphs by Jean-François Champollion himself. He met with Champollion twice in Rome, in 1825 and 1826. Kestner learned hieroglyphs in lectures given by Champollion. Kestner can therefore be considered as the first German to learn the correct translation system of Egyptian hieroglyphs.

In Rome, Kestner was among the founders of the archaeological group 'The Roman Hyperboreans' (1823), which became 'Instituto di Corrispondenza archeologica' in 1828. This institution was the predecessor of today's German Archaeological Institute. In 1836 Lepsius came to Rome to be the editorial secretary at the institute for two years. Kestner was also vital for Lepsius' expedition to Egypt and the Sudan.

Kestner bequeathed his entire collection to his nephew demanding that it be given to his native city of Hanover if the city was willing to build a museum for it. This was indeed realized and the 'Kestner-Museum' opened its doors in November 1889, making available to visitors almost 1,000 Egyptian artefacts then the second largest public Egyptian collection in Germany (after Berlin with 10,000 Egyptian artefacts).

The scarab Inv. No. 2151 was donated to Hanoverian diplomat, art collector, and founding father of the museum bearing his name, August Kestner, by Lepsius. It may have been brought to him by some expedition members after they had returned to Europe and were visiting Kestner in Rome in November $1845 .{ }^{9}$ Lepsius did not bring for Kestner only the scarab in question, but also original antiquities, which form part of the collection of Museum August Kestner. Unfortunately, it is not known which pieces in his collection were gifts from Lepsius, but for the scarab bearing his name.

The Hanoverian scarab looks astonishingly authentic; for non-specialists, it is undistinguishable from genuine pieces from ancient Egypt. The piece is $4.5 \mathrm{~cm}$ long, $2.0 \mathrm{~cm}$ wide, and $2.0 \mathrm{~cm}$ high. It is finely carved. The material is glazed steatite, typical for the

7 Erbkam 2007; The diary of Erbkam is published online only - available at: http://pom.bbaw.de/erb$\mathrm{kam} / \# / 1000$ [Accessed 2 November 2020].

8 Loeben 2013, p. 29, no. 15; Loeben 2017, p. 46; Loeben 2020.

9 See Erbkam's diary entry which mentions visiting Kestner in Rome for 28 October and 2 November 1845 - available at: http://pom.bbaw.de/erbkam/\#/1165 and http://pom.bbaw.de/erbkam/index.html\#/1170 [Accessed: 2 November 2020, ...exactly 175 years later]. 
majority of all Egyptian scarabs (small or big). The base of the scarab is inscribed with six lines of signs imitating ancient Egyptian hieroglyphs. The text is perfectly understandable and reads as follows:

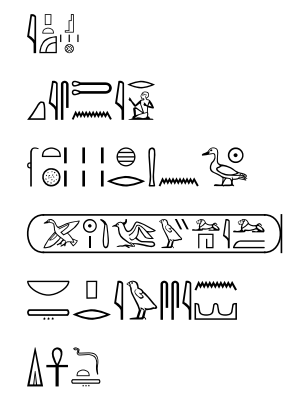

Line 1 jp.tsw.t Thebes

Line $2 \quad k-j-s-t-n-j-r \quad$ Kestner

Line 3 rnp.t-sp 6 hr hm n s3r $\quad$ Year 6 under the Majesty of Son of Ra

Line $4 \quad\left(p 3-r^{\ulcorner}\right.$tj $\left.r h y . t w-y-l-h-j-l-m\right) \mid$ (Paratarekhyt [= Friedrich] Wilhelm) |

Line $5 n b t 3 p-r-j-w-s-s-j-n \quad$ Lord of the Land of Prussia ('Preussen' in German),

Line $6 \quad$ dj ${ }^{\top} h \underline{h} \underline{d} . t \quad$ given life forever!

Line 1 locates the production of the scarab. It must have been produced by a local artisan in Luxor, as indicated by the Theban local name for Karnak, Ipet-sut. The toponym is flanked by a pair of uraei. Line 2 gives the surname of the prospect owner, i.e. (August) Kestner. Lines 3-4 provide the dating of the piece to Year 6 of King Friedrich Wilhelm IV of Prussia. As Friedrich Wilhelm IV ascended the throne on 4 June 1840, following the ancient Egyptian system of counting regnal years, Year 6 corresponds to year 1845 CE. For the text on the base of the scarab, Lepsius developed an ancient Egyptian version of the name 'Friedrich', namely Pa-ra-ta-rekhyt - 'the Sun of the People' (i.e. 'subjects').

The writing of the king's first name, Friedrich, underwent a relatively complex development. In the Crown Princess Elisabeth titulary, the chronologically earliest inscription discussed in the present paper, the name of the Crown Prince is written as $(f-r-y-d-r-y-k-h w-y-l-h-j-l-m) \mid$, while the Giza graffito presents a tendency to find a phrase in ancient Egyptian which would be homonymous or close to homonymous to the German name of Friedrich. In the Giza graffito the name is written as $([p]]-r^{r}-\underline{t}-j r-h$ $w-y-l-h-l-m) \mid$, while the writing is much more developed in the case of the Hanoverian scarab, where the name $\left(p_{3}-r^{\ulcorner}\right.$tj rhy.t $\left.w-y-l-h-l-m\right)$ is employed. Both renderings appear to be versions of the same, presenting Friedrich Wilhelm IV as 'the Sun of the People'.

In Line 5, the king is titled as the sovereign of Prussia, which is written in German as 'Preussen' ('ss' for ' $B$ ') following the conventions Lepsius developed for writing of non-ancient Egyptian words (cf. below). Line 6 gives the epithet of a king: 'given life forever'. 
The Hanoverian scarab extended the range of people for whom the scarabs were produced from the expedition members mentioned by Erbkam to Lepsius's friends and acquaintances (in Europe).

\section{Scarab base imprints Prague Inv. Nos. P 284 and P 285}

In 2010, the City of Prague Museum (Muzeum hlavního města Prahy) published a volume in Czech commemorating eighty years that had passed since the death of the prominent Czech archaeologist Josef Antonín Jíra (1868-1930). ${ }^{10}$ On that occasion, a publication of Jira's Egyptian collection, currently kept in the Náprstek Museum, was also published. ${ }^{11}$ Alongside an almost complete human mummy and a handful of original pieces, Jíra's collection included numerous imprints of scarab bases.

Through Jíra's diary and other records, we are aware of their origin. In 1905, the famous Czech antiquarian Josef Ginz (1857-1912) offered a set of Egyptian scarabs for sale in his antiquarian shop in Kostelec nad Černými Lesy. Ginz must have known about Jíra's lifelong interests in ancient Egypt and its antiquities, as three years earlier, Jíra had already purchased a couple of Egyptian antiquities from Ginz. We do not know why Jíra eventually did not purchase these scarabs but instead imprinted them into sealing wax.

The scarabs Jíra made imprints of were all, except one, of modest dimensions (maximum length of ca. $2 \mathrm{~cm}$ ). This one exception was a scarab of bigger size than the average normal Egyptian scarabs would be, a bit smaller than the typical Egyptian heart scarab (height of ca. $4.5 \mathrm{~cm}$ ), which Jíra copied twice (Náprstek Museum, Inv. Nos P 284 and P 285) [Pl. 3]. The base of this scarab was inscribed with six lines of hieroglyphic text. The text had initially been identified as a modern composition produced by a person with a considerable knowledge of ancient Egyptian language and script. ${ }^{12}$ Later the imprinted scarab was identified as another specimen from the series produced on Lepsius' request in May 1845 at Luxor. The texts on the imprints found their direct parallel in the text on the base of the Hanoverian scarab Inv. No. 2151.

In the moment that Jira impressed the scarab into sealing wax, the scarab was already damaged to some extent. The top right part of its base must have been broken off. As a result, Line 1 of the text is almost illegible, while the initial sections of Lines 2 and 3 are missing. Based on the parallel in the Hanoverian piece, the text on the Prague imprints may be reconstructed as follows:

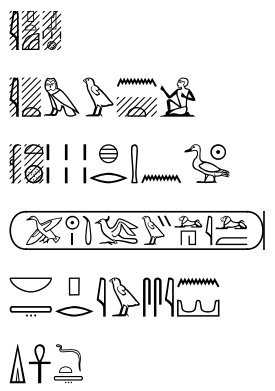

10 Hlava 2010.

11 Onderka 2010; for Jíra's Egyptian collection see Appendix.

12 Onderka 2010, pp. 455-456. 


$\begin{array}{lll}\text { Line } 1 & {[j p . t s w . t]} & \text { [Thebes] } \\ \text { Line } 2 & {[\ldots]-m-w-[\ldots]-t} & {[\ldots] \mathrm{mu}[\ldots] \mathrm{t} / \mathrm{d}} \\ \text { Line3 } & r n p . t-s p 6 h r h m n s 3 r^{c} & \text { Year } 6 \text { under the Majesty of Son of Ra } \\ \text { Line } 4 & \left(p 3-r^{\odot}[t j] r h y . t w-y-l-h-j-l-m\right) & \text { (Para[ta]rekhyt [=Friedrich] Wilhelm) | } \\ \text { Line } 5 & n b t 3 p-r-j-w-s-s-j-n & \text { Lord of the Land of Prussia, } \\ \text { Line 6 } & \underline{d} j{ }^{\odot} n h \underline{d} . t . & \text { given life forever! }\end{array}$

In Line 2, which was reserved for the inscription of the prospect owner, only three signs are legible. The initial part, corresponding to a unit square, provides space for a tall broad sign, or a combination of several tall narrow, low broad, or low narrow signs. ${ }^{13}$ There, follows two tall broad bird signs, namely G17 (owl) and G43 (quail chick) of the Gardiner's list. The text continues with the low narrow $\mathrm{X} 1$ (bread) sign placed above the lower line divider. The space above the X1 sign is damaged and with all probability contained a low broad sign. The line is concluded by the A1 (seated man) sign, which in all probability served as the male name's determinative.

Name indexes in Lepsius' biographies, ${ }^{14}$ and histories of Egyptology provide dozens and dozens of names of people that played a more or less important role in Lepsius' life. Based on the signs preserved in Line 2, one may exclude all expedition members, so the intended recipient must have been somebody Lepsius had been acquainted with before leaving Europe for Africa in 1842, i.e. before he turned 33. By that age, Lepsius was a well-travelled intellectual with contacts across Europe and family as well as academic background in his native Prussia.

For the sake of the reconstruction of the original owner's name one needs to examine Lepsius' conventions for hieroglyphic writing of modern personal and local names. Lepsius' 'General phonetic alphabet' provided in the plates of Lettre a M. le Professeur H. Rosellini $i^{15}$ may serve as a starting point [Fig. 1], while rendering of the names in the previously mentioned texts, namely the titulary of Crown Princess Elisabeth $\{E\}$, the Giza graffito $\{\mathrm{G}\}$ and the Hanoverian scarab $\{\mathrm{H}\}$ shall provide more specific pieces of information [Tab. 1].

After trying possible combinations of signs, the personal name Edmund, rendered as $j$-t-m-u-n-t , seems most likely to be the word given in Line 2 of the Prague imprints. Based on the Giza graffito and the Hanoverian scarab, one would expect a surname to be written in the line; however, nobody with the surname Edmund has been identified in Lepsius' biography. Edmund as a first name could be considered in the case of people who were really close to Lepsius or were even his family members. Among the eight siblings of Karl Richard was his older brother Karl Edmund (1805-1873) who was the most likely original recipient and owner of the scarab, that 32 years after his death was present in Bohemia, several kilometres from Prague. Its whereabouts since then and today are unknown.

13 Cf. Gardiner 1950, p. 548.

14 e.g. Ebers 1885; Erbkam 2007; Freier and Reinecke 1988; Mehlitz 2011.

15 Lepsius 1837, Pl. A. 
Tab. 1. Proper names in hieroglyphic texts composed by Lepsius.

\begin{tabular}{|c|c|}
\hline $\multicolumn{2}{|c|}{E}=$ Titulary of Crown Princess Elisabeth \\
\hline 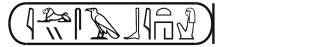 & Elisabeth \\
\hline 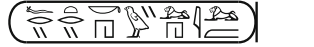 & Friedrich Wilhelm \\
\hline $4=\frac{2 x}{11}$ & Maximilian \\
\hline 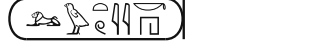 & Ludwig \\
\hline SAB PARA & Preussen \\
\hline 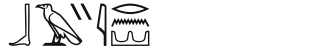 & Bayern \\
\hline $\multicolumn{2}{|c|}{G}=$ Giza graffito \\
\hline 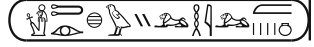 & Friedrich Wilhelm IV \\
\hline 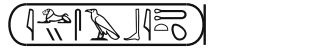 & Elisabeth \\
\hline$\stackrel{x \rightarrow A A B}{a}$ & Lepsius \\
\hline$\underset{\infty}{\infty} \|_{\Delta l}$ & Erbkam \\
\hline 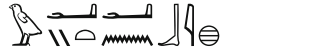 & Weidenbach \\
\hline$\sum_{111}$ & Frey \\
\hline SOf & Franke \\
\hline $\int f_{0} f \approx$ & Bonomi \\
\hline$g^{\prime \prime}$ & Wild \\
\hline o $8=\pi_{11} y_{2}$ & Rhein \\
\hline $\multicolumn{2}{|c|}{\mathrm{H}}=$ Hanoverian scarab \\
\hline 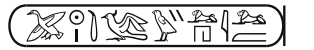 & Friedrich Wilhelm \\
\hline$\Delta 4 \|_{\text {mmm }}^{\infty}$ & Kestner \\
\hline S4beflin & Preussen \\
\hline
\end{tabular}


Tab. 2. Hieroglyphic signs used by Lepsius to render the German alphabet.

\begin{tabular}{|c|c|c|c|c|}
\hline German alphabet & $\{E\}$ & $\{G\}$ & $\{H\}$ & $\{P\}$ \\
\hline A & $B$ & $B, 4,1=0$ & & \\
\hline B & I & I & & \\
\hline C & & & & \\
\hline D & ○ & $0, \approx$ & & $\triangle(?)$ \\
\hline $\mathrm{E}$ & 4 & $4=0$ & 4 & \\
\hline $\mathrm{F}$ & 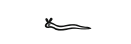 & $\approx$ & & \\
\hline G & म & & & \\
\hline $\mathrm{H}$ & 口 & \& & 同 & \\
\hline 1 & $A A, \ldots$ & $A A, \cong$ & 11 & \\
\hline $\mathrm{J}$ & & & & \\
\hline K & & $\Delta$ & $\Delta$ & \\
\hline $\mathrm{L}$ & 20 & s & 20 & \\
\hline M & 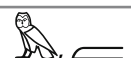 & $\digamma$ & $\lessdot$ & 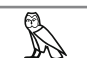 \\
\hline $\mathrm{N}$ & m.m, 0 & . & m & \\
\hline $\mathrm{O}$ & & fo & & \\
\hline$P$ & 口 & Q & $\square$ & \\
\hline Q & & & & \\
\hline $\mathrm{R}$ & 0 & 0 & $\infty$ & \\
\hline $\mathrm{s}$ & १ & १ & п & \\
\hline$T$ & ○ & $0, \infty$ & $\infty$ & $\triangle(?)$ \\
\hline u & $\beta$ & $\beta$ & & $\beta_{0}(?)$ \\
\hline v & & & & \\
\hline w & $B, \rho$ & $B$ & $\beta$ & $\beta_{a}(?)$ \\
\hline$x$ & 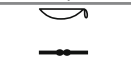 & & & \\
\hline$Y$ & & 11 & & \\
\hline z & & & & \\
\hline B & ק & & 饫 & \\
\hline$[: \mathrm{CH}:]$ & $\overrightarrow{0}$ & $\theta$ & & \\
\hline
\end{tabular}




\section{Conclusions}

The study of Karl Richard Lepsius' modern hieroglyphic compositions enabled us to identify the original owner of the scarab of Josef Antonín Jíra, copied in 1905 in the antique shop in Kostelec nad Černými Lesy, now Czech Republic as Karl Edmund Lepsius, brother of the Egyptologist.

The reference in Erbkam's diary, combined with the evidence provided by the Hanoverian scarab and the Prague scarab base imprints, attests to a wide scope of people for whom Lepsius had produced scarabs with names inscribed. Next to the expedition members, Lepsius seems to have presented the scarabs to his friends, acquaintances (including sponsors and donors), and last but not least his family members. One may thus anticipate the existence of further similar scarabs that Lepsius had produced in Luxor in 1845. The total number of these scarabs must have gone into the dozens, while only two are known to the scholarly community at the moment. More scarabs are most likely deposited either unrecognized in public collections that are not curated by Egyptology experts, or are still in private hands (e.g. descendants of the Lepsius expedition members and his acquaintances, members of the extended Lepsius family).

The scarabs Lepsius had produced in Luxor in 1845 tell us much about the imitations/forgeries of Egyptian antiquities of the period in question. A workshop, with the capability of fabricating incredibly genuine-looking imitations of ancient Egyptian antiquities, must have existed in Luxor in 1845, under the guidance of an Egyptologist. The study of the Lepsius scarabs hence gives us an early glimpse on the production of imitations and forgeries of Egyptian antiquities.

Lepsius established a still existing, and even flourishing tradition of souvenir production, which employs transcriptions of modern names into ancient Egyptian hieroglyphs. Present-day visitors to the süqs of Cairo and Luxor still purchase pendants in the shape of cartouches containing their name, or names of their beloved, in Egyptian alphabetic hieroglyphs made by local goldsmiths and silversmiths.

\section{Appendix: Josef Antonín Jíra and Egyptian antiquities ${ }^{16}$}

Josef Antonín Jíra [Pl. 4] was born on 19 June 1868 in Heřmanova Hut', then Austria-Hungary (now Czech Republic). His mother and father died in 1870 and 1871, respectively. As a result, Josef was in care of both his paternal and maternal relatives. Since the age of five, Josef joined his paternal aunt in Litomyšl, while his maternal uncle acted as his official legal guardian. In Litomyšl, he attended both the local grammar school and the high school ('Gymnasium' in German). It was already during these school years that he developed a keen interest in archaeology and collecting. This was further developed thanks to the first Czech archaeological journal Památky archeologické a mistopisné, which he loaned on a regular basis from a friend's father's library. In the summertime, young Jíra travelled across Bohemia, visiting prehistorical and medieval sites collecting archaeological material.

Jíra was attracted to the pharaonic culture thanks to the great discoveries by Heinrich Brugsch (1827-1894) and Gaston Maspero (1846-1916) in the late $19^{\text {th }}$ century, especially by the discovery of the so-called Cache royale at Deir el-Bahari. Jíra became

16 As the personality of Josef Antonín Jíra is almost unknown to the international Egyptological community, the authors consider it necessary to provide a short biography and history of his Egyptian collection, especially since the above-mentioned monograph on Josef Antonín Jíra, (Hlava 2010), including a chapter on his relation to Egyptology (Onderka 2010), were published in Czech only. 
deeply interested in Egyptology and decided to send a letter to both above-mentioned scholars, requesting a mummy for his private collection (cf. below). Both Brugsch and Maspero allegedly agreed to the request; however, the venture was stopped by Jíra's legal representative. Nevertheless, Jíra kept the replies by the famous Egyptologists as a remembrance of this enterprise. ${ }^{17}$

Jíra indeed wanted to become a professional Egyptologist. If he had succeeded with this plan, he would have become the first Czech Egyptologist. Alas, this plan was swiftly rejected by his legal representatives. Jíra decided to make it to his beloved Egypt through a detour. His plan included studying medicine and as a navy medical officer to eventually travel to his beloved Egypt. In 1887, Jíra enlisted at the medical faculty in Prague. At the same time, he became widely engaged in archaeological excavations, as well as exhibition presentation.

In 1895, Jíra significantly participated on the Czechoslavic Ethnographical Exhibition in Prague (Národopisná výstava českoslovanská v Praze). Involvement in the event paved the way for his future professional museum career. In 1896, at about the time he completed his studies of medicine, Jíra was offered a job at the Czechoslavic Ethnographic Museum, which meant he took care of the assemblage of most exhibits for the exhibition. By the beginning of the $20^{\text {th }}$ century, Jíra's interest in Egyptology got overshadowed by his activities and successes in the field of regional archaeology.

Finally, after the independence of Czechoslovakia in 1918, Jíra was appointed a conservator of archaeological finds at the National Institute of Archaeology in Prague. Jíra passed away on 22 January 1930 in Prague, Czechoslovakia (now Czech Republic).

Jira started developing his own private collection at an early age, which included several Egyptian antiquities. During the time he attended the high school (Gymnasium) at Litomyšl, his teacher, a certain Professor Bárta, donated to young Jíra 'a bronze figure of an Apis bull' (Náprstek Museum, Inv. No. P 1884) and 'a striding figure with a vessel placed on its head' (Náprstek Museum, Inv. No. P 1948) - an actual bronze figure of Nefertem.

The high school in Litomyšl possessed its own teaching collection which consisted of Egyptian antiquities. Among them was a shabti belonging to the royal seal bearer Paabumeh (with the 'beautiful name' Psamtekseneb), son of Aakha and Tawepetneferet. The original piece did not survive; however, the sulphur cast, made by Jíra during his high school years, did (Náprstek Museum, Inv. No. P 148). The last object which Jíra gained in his early years was a purchase from Rudolf Svoboda of a statue of the goddess Isis with Horus on her knees, allegedly coming from Pompeii, Italy; the present location of this antiquity is not known.

Jíra's great wish to have a genuine Egyptian mummy in his possessions came true in 1893, when he was living in Prague, aged 25. The acquisition of the mummy was vividly described by Stanislav Kodym (1869-1958), the librarian of the Náprstek Museum who authored Jíra's biography. ${ }^{18}$ The mummy (Náprstek Museum, Inv. No. P 633) ${ }^{19}$ was present in Prague at the latest by the end of the $18^{\text {th }}$ century, when it was recorded in the book by Jaroslav Schaller which was titled Beschreibung der königlichen Haupt- und Residenzstadt Prag and published in $1796 .^{20}$ Then, the mummy was owned by a certain Václav Barka, a shop owner at the Old Town address Na Perštýně 346. Jíra should have bought the mummy together with its bandages. However, the bandages (Náprstek

17 Kodym 2010, p. 33.

18 Kodym 2010, pp. 44-45.

19 Onderka, Jungová et al. 2016, pp. 44-47.

20 Schaller 1796, p. 346. 
Museum, Inv. No. P 514) do not seem to belong to the mummy, as the dating of the bandages to the Ptolemaic Period conflicts with the dating of the mummy to the Third Intermediate Period.

In June 1894, Jíra purchased 'an Egyptian porcelain figure', i.e. a Late Egyptian shabti made of Egyptian faience (Náprstek Museum, Inv. No. P 1345) from his colleague Ot. Kronský.

Sometime between 1897 and 1898, Jíra purchased further six Egyptian antiquities from the famous Czech numismatist and antiquities dealer named Karel Chaura (18691945). The new accession consisted of a shabti made of Egyptian faience (Náprstek Museum, Inv. No. P 152), a fragment from another shabti of the same set (Náprstek Museum, Inv. No. P 151), dated to the turn of the Late and Ptolemaic Periods, an upper part of a Ptolemaic statue of Ptah-Sokar-Osiris (which Jíra wrongly identified as a shabti; Náprstek Museum, Inv. No. P 20), a bronze statue of Osiris (Náprstek Museum, Inv. No. P 1940), and a damaged faience amulet depicting the deity Anubis (Náprstek Museum, Inv. No. P 2316).

In 1900, Jíra found a New Kingdom shabti (Náprstek Museum, Inv. No. P 180) at some premises where an exhibition dedicated to architecture was held.

The last Egyptian accession to Jíra's collection came in 1902. Jíra bought a set of Egyptian antiquities from Josef Ginz (1857-1912), an antiquarian dealer from Ždánice (east of Prague), who ran a shop specializing in antiques and rare books in Kostelec nad Černými Lesy. No details were provided concerning these antiquities. One may assume that they were identical with the genuine Egyptian antiquities from the Jira collection which have not been mentioned so far, including a denuded bronze statuette of Osiris (Náprstek Museum, Inv. No. P 74) and a bronze statuette of a male divinity (Náprstek Museum, Inv. No. P 479). However, this assumption may be wrong.

In 1905, Ginz and Jíra were in contact again because of Egyptian antiquities, namely 'seals and scarabs'. This time, Jíra did not buy the antiquities, but Ginz allowed him to imprint them into 'putty' (or more precisely sealing wax; Náprstek Museum, Inv. Nos. P 283 [16 pieces], P 284 and P 285).

In 2012, the Náprstek Museum received a donation of another imprint in seal wax, which allegedly had originally come from Jíra's possession. The similarity between the character of objects imprinted and the material used for the imprint makes the claim concerning its provenance likely.

The Jira Collection later became part of the City of Prague Museum, from where the Egyptian part was transferred to the Náprstek Museum on 13 April 1964.

\section{Literature:}

Champollion, J.-F. (1836). Grammaire égyptienne, ou principes généraux de l'écriture sacrée égyptienne appliquée à la représentation de la langue parlée. Paris: Didot Frères.

Ebers, G. (1885). Richard Lepsius: ein Lebensbild. Leipzig: Engelmann.

Erbkam, G. G. (2007). Tagebuch meiner egyptischen Reise. Transcribed by E. Freier and S. Grunert. Edited by the Arbeitsgruppe Altägyptisches Wörterbuch der Berlin-Brandenburgischen Akademie der Wissenschaften. [online] Berlin-Brandenburgische Akademie der Wissenschaften. Available at: http://pom.bbaw.de/erbkam/ [Accessed: 2 November 2020].

Freier, E. and Reineke, W. F. (1988). Karl Richard Lepsius (1810-1884): Akten der Tagung anlässlich seines 100. Todestages, 10.-12.7.1984 in Halle. Schriften zur Geschichte and Kultur des Alten Orients 20. Berlin: Akademie-Verlag. 
Gardiner, A. (1950). Egyptian grammar: being an introduction to the study of hieroglyphs. Oxford: Oxford University Press.

Hlava, M., ed. (2010). Archeologica Pragensia: archeologický sborník Muzea hlavního města Prahy: věnováno Josefu Antonínu Jírovi u přiležitosti 80 let od jeho úmrtí, 20/2010. Praha: Muzeum Hlavního města Prahy.

Kodym, S. (2010). Josef A. Jíra Jeho život a jeho dílo - Josef Antonín Jíra. His life and work. In: M. Hlava, ed., Archeologica Pragensia: archeologický sborník Muzea hlavního města Prahy: věnováno Josefu Antonínu Jírovi u př́ležitosti 80 let od jeho úmrtí, 20/2010. Praha: Muzeum Hlavního města Prahy, pp. 28-124.

Lepsius, K. R. (1837). Lettre à M. le professeur H. Rosellini [...] sur l'alphabet hiéroglyphique. Rome.

Lepsius, K. R. (1852). Briefe aus Aegypten, Aethiopien und der Halbinsel des Sinai: geschrieben in den Jahren 1842-1845 während der auf Befehl Sr. Majestät des Königs Friedrich Wilhelm IV. von Preußen ausgeführten wissenschaftlichen Expedition. Berlin: Wilhelm Hertz.

Loeben, C. E. (2010). L'expédition en Égypte de Karl Richard Lepsius (1842-1845). In: S. Aufrère and T.-L. Bergerot, eds., Égypte: Grandes expéditions - XVIIIe E XIXe siècles. Catalogue d'exposition - Gordes, du 26 juin au 26 septembre 2010. Avignon: Centre d'Égyptologie, pp. 153-166.

Loeben, C. E. (2011). Die Aegyptiaca in der Sammlung von August Kestner. In: C. E. Loeben, Die Ägypten-Sammlung des Museum August Kestner und ihre (Kriegs-)Verluste. Museum Kestnerianum 15. Rahden/West.: Verlag Marie Leidorf, pp. 41-59.

Loeben, C. E. (2013). Für August Kestner beschrifteter Skarabäus. In: Bürgerschätze: Sammeln für Hannover/ 125 Jahre Museum August Kestner. Museum Kestnerianum 19. Hannover: Museum August Kestner, p. 29.

Loeben, C. E. (2017). Quelques scarabées peu ordinaires dans la collection égyptienne du Museum August Kestner de Hanovre. Égypte Afrique E Orient, 85 (avril-mai 2017), pp. 35-46.

Loeben, C. E. (2020). Karl Richard Lepsius and the Royal Prussian Expedition to Egypt (1842-1845/6). In: V. Davies and D. Laboury, eds., The Oxford handbook of Egyptian epigraphy and palaeography. New York: Oxford University Press, pp. 243-256.

Mehlitz, H. (2011). Richard Lepsius: Ägypten und die Ordnung der Wissenschaft. Berlin: Kadmos.

Onderka, P. (2010). Josef Antonín Jíra a starověký Egypt - Josef Antonín Jíra and Ancient Egypt. In: M. Hlava, ed., Archeologica Pragensia: archeologický sborník Muzea hlavního města Prahy: věnováno Josefu Antonínu Jirovi u př́ležitosti 80 let od jeho úmrtí, 20/2010. Praha: Muzeum Hlavního města Prahy, pp. 443-457.

Onderka, P., Jungová, G. et al. (2016). Atlas of Egyptian mummies in the Czech collections, I: complete adults human mummies. Prague: National Museum.

Schaller, J. (1796). Beschreibung der königlichen Haupt- und Residenzstadt Prag. Prag: F. Gerzabeck.

Wakeling, T. G. (1912). Forged Egyptian Antiquities. London: Adam \& Charles Black. 


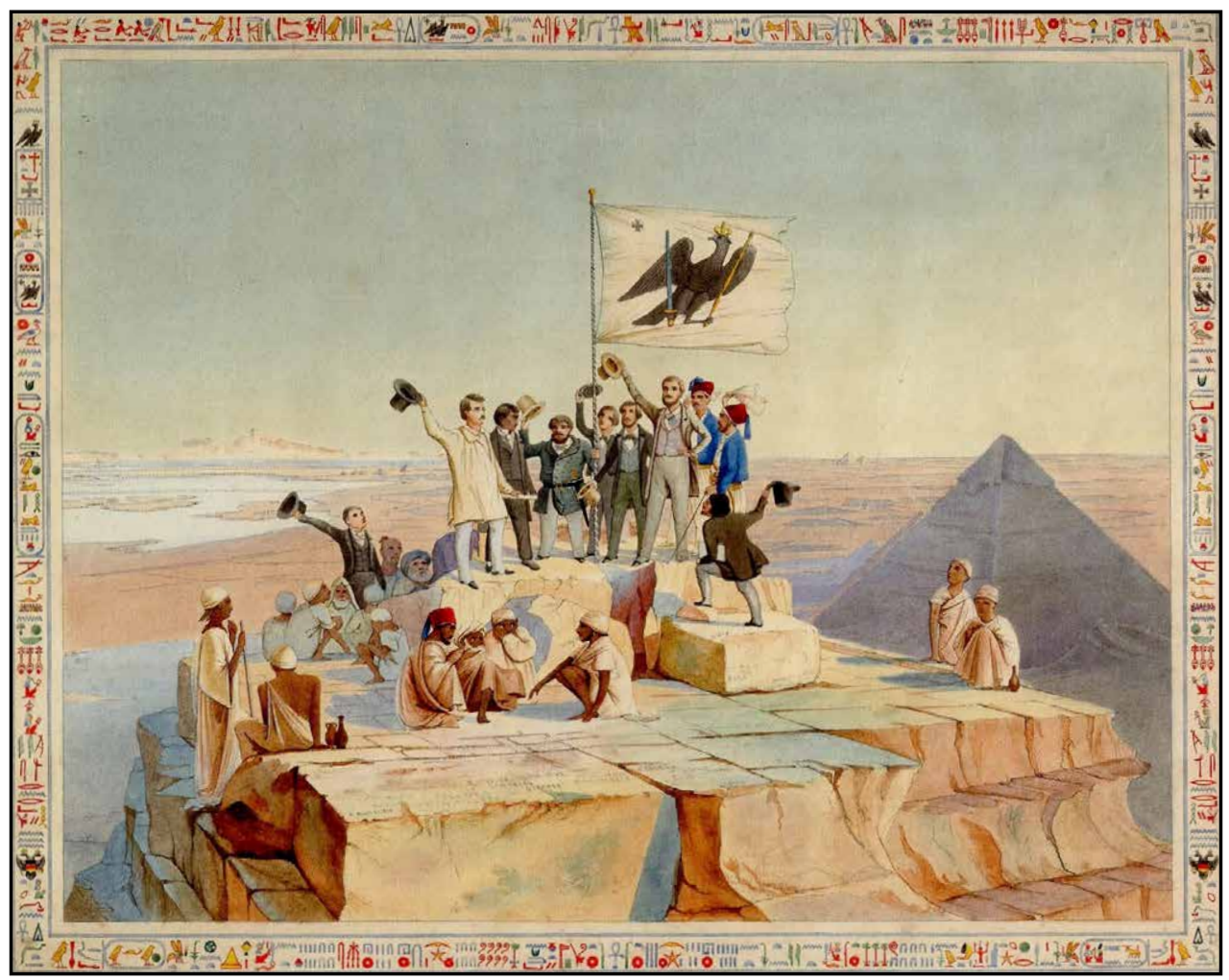

Pl. 1. Johann Jakob Frey: Die preußische Expedition auf der Cheops Pyramide am 15. Oktober 1842. (C) Ägyptisches Museum und Papyrussammlung, Berlin.
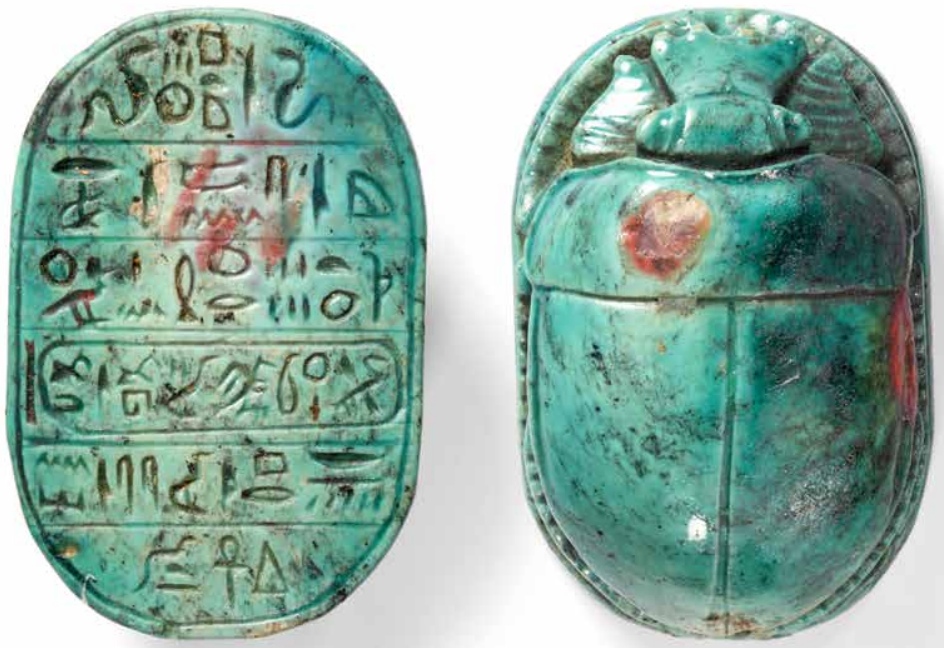

P1. 2. Scarab from the collections of Museum August Kestner, Inv. No. 2151. (c) Museum August Kestner, Hanover, Inv. No. 2151. 


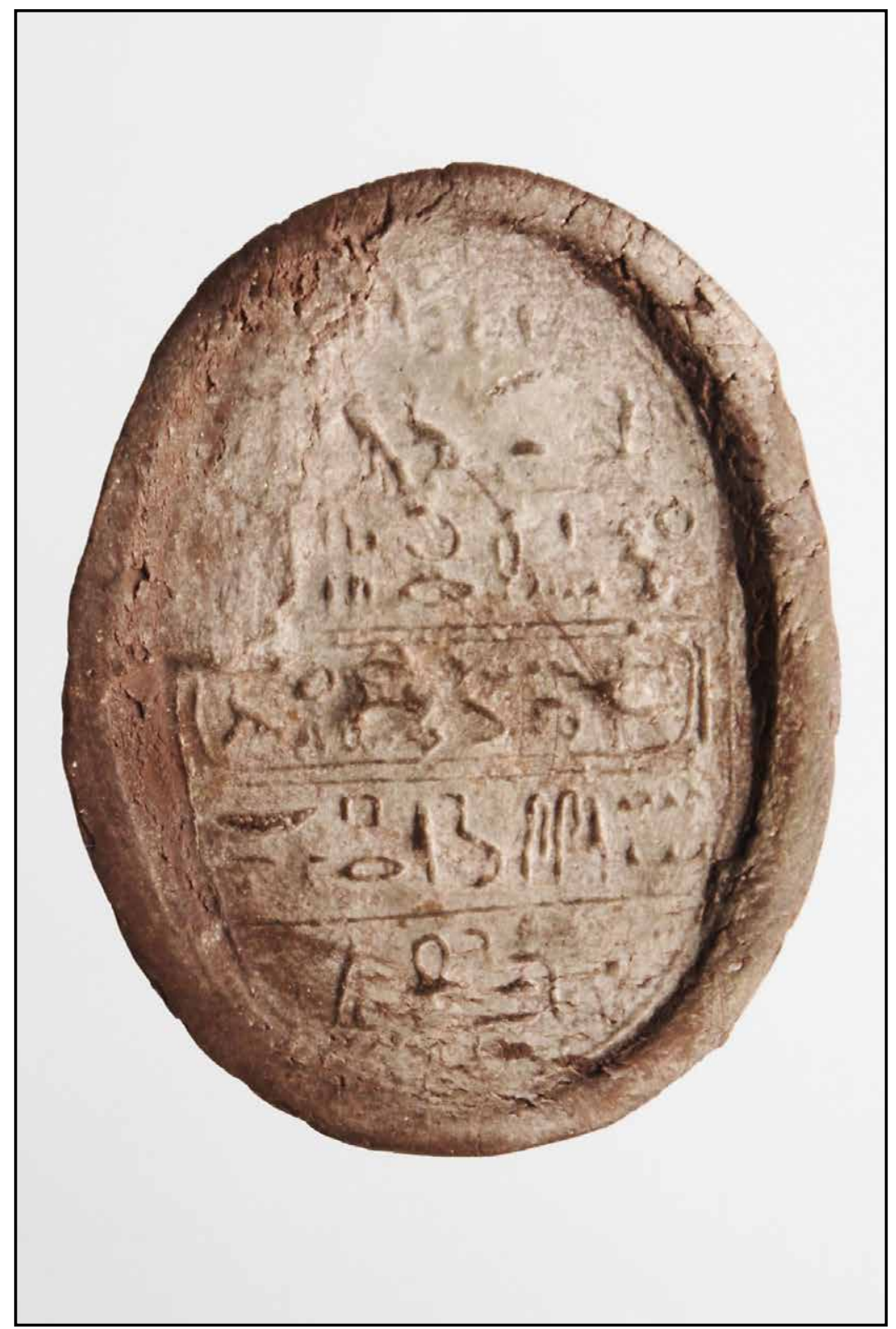

Pl. 3. Scarab base imprint from the collections of the Náprstek Museum, Inv. No. P 284. 


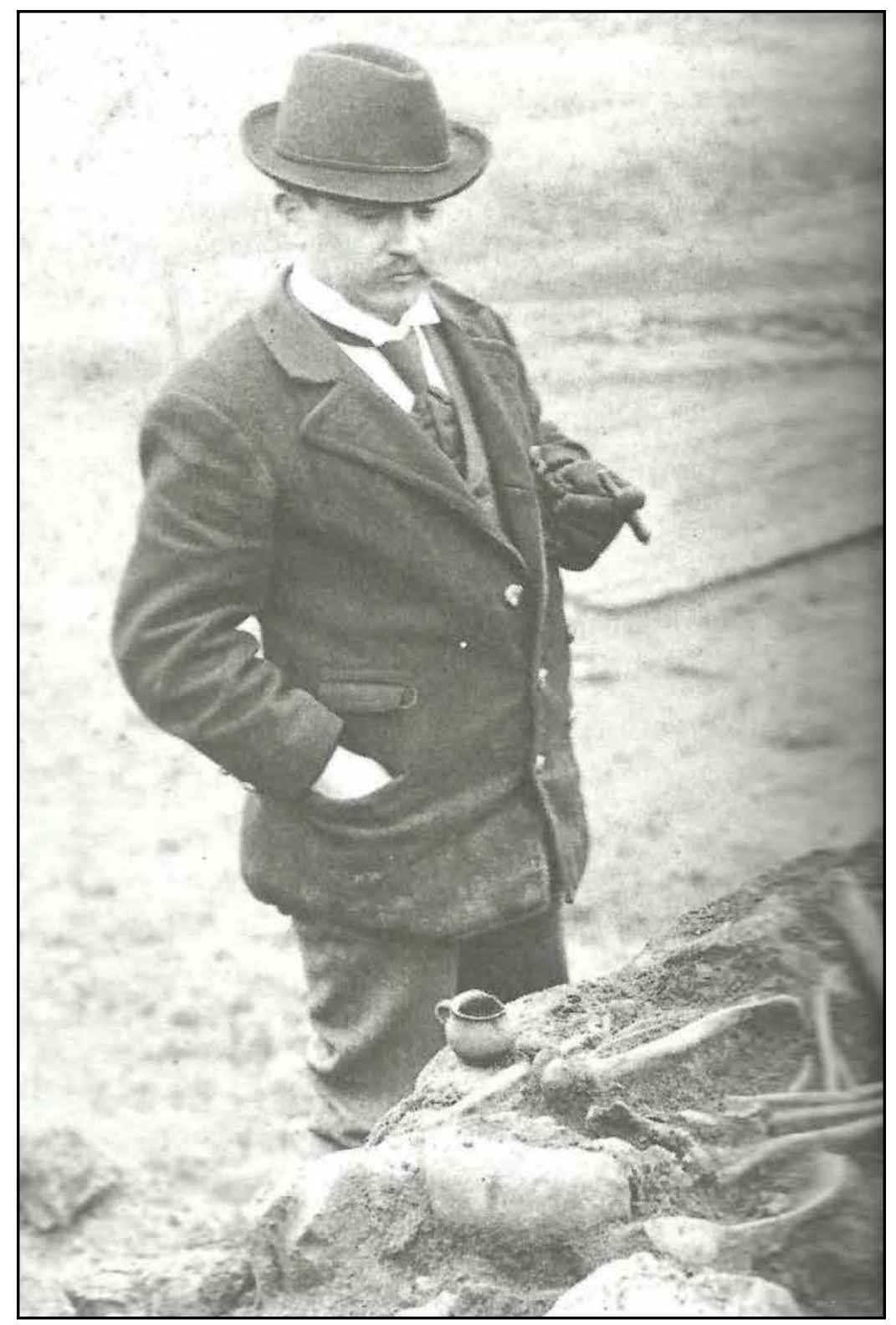

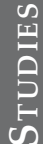

Pl. 4. Josef Antonín Jíra. 